【特 集：循環型社会構策に向けての廃棄物経済の課題と展望一研究委員会研究活娌（維済部会）-】

\author{
これからの 環 境 保 全 活 動
}

山口耕二*

【要 旨】これからの環境保全活動は，今までとはまさに様変わりした内容や行動が求められている。 行政では, 廃裹物に関する現状問題点を直視した廃裹物処理法の改正やリサイクル支援法の拡大的な適 用がある。産業界でも, 経団連が 7 月に発表した環境アピールで判るように, 循環型社会づくりに向け 一歩を踏み出した。このアピールでは，廃棄物を資源・副産物と位置付け資源の効率的な利用を各企業 に呼び烓けている。国際的な視点では，今まで技術標準を作成してきた国際標準化機構が，環境に関す る国際規格づくりに着手し環境管理システムとそれをチェックするための環境監查に関する規格を発行 した。当社においては，廃棄物ゼロ運動を全社的な目標と設定し 11 年前から実施しており，大きな成 果を出している。このように, 環境問題のなかで, 廃棄物の削減再資源化は環境保全の基本であり，ま た全社的な活動を展開するのに最も取り組みやすいテーマの一つである。

キーワード：廃掃法改正, 廃製品回収リサイクル, 経団連アピール, 廃裹物ゼロ運動, 環境管理システ $\triangle$

1.はじめに

92 年に開催された地球サミットを契機に, 企業や行 政の環境問題への取り組み姿勢が大きく変わってきた。

環境問題が, 地球温暖化やフロンガスによるオゾ首 破壊などまさに地球規模的となり，これらの解決策も多 くの問題が絡み合いますます複雑になってきた。

また, 廃棄物問題が, 今までのように排出された不要 物の考えから資源問題となり, 製品開発や製造プロセス 開発など企業行動の在り方を根本から見直さなければい けなくなってきた。

\section{2. 国内における最近の環境動向}

\section{1 行政の動き}

廃裹物に関する最近の動きの一つに，不法投棄に対す る対策強化之，新たな処分場建設およびリサイクルを促 進するための廃棄物処理法改正がある。

今回の法改正は, 廃栽物に対する考え方が, 捨てる物

原稿受付 1996.10.16

*日本電気株式会社 環境管理部長

連絡先: $=108-01$ 東京都港区之芝 5 丁目 7-1
国内における，最近の廃棄物動向

廃棄物処理法の改正 (予定)

$\Rightarrow$ 不法投裹対策, 埋立て処分場の適正化

$\diamond$ 廃棄物の抑制とリサイクルの推進

$\diamond$ 産業廃㪰物処分場の整備促進

処分場新設時のアセスメント

$\diamond$ 不法投裹・不適生処理の防止策強化

全ての産業廃棄物にマニフェスト制度適用

不法投裹に罰則を強化

現状の不法投棄は産業界の責任で原状回復

から回収・リサイクルすなわち資源であるとの認識に変 わってきた一つの表れである。

次期国会でこの改正法案が承認され，廃棄物に対する 新たな 1 ページが開かれると期待する。

\section{2 使用済み製品の回収・リサイクル問題}

処分場の残余年数や新規設置の困難さ，処分場からの 有害物質容出などの廃棄物問題を根本から見直す政策と して，また，資源枯渴問題への対応のため，使用済み製 品の回収・再資源化問題がクローズアップされてきた。

企業や自治体は，廃製品の回収リサイクルへの対応に 今までにないような視点で積極的に取り組んでいる。し かしこの問題の解決には, 消費者など市民の協力なくし 


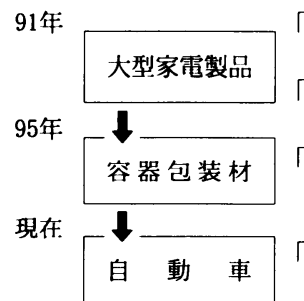

「リサイクル法」

リサイクルを考慮した設計

「廃掃法改正」 自治体の回収処理に協力

「容器包装リサイクル法」

自治体が囘収, 事業者が再原料化

「産業構造審議会で審議中」

シュレッタダストのリサイクル促進

近い

将来

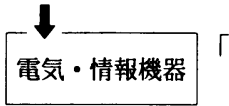

「産業構造審議会で検討開始」

仕組みの検討

てはなかなか難しい。

企業・行政・市民が一体となり, 循環型社会づくりに

邁進する必要がある。

大型家電から始まった回収・リサイクルは, ペットボ トルなどの飲料容器に広がりさらに自動車へと多くの消 費財が対象になってきた。

\section{3 産業界の動き}

96 年 7 月に, 経団連が産業界の環境に対する考え方 「環境アピール」を発表した。循環型社会作りの必要性 を認識し，産業界のスタンスを改めて明確にすることを 提示している。

この中でも，廃棄物に対する考え方を根本から見直し た。すなわち廃棄物は資源・副産物と発想の転換を宣言 した。

経団連が環境アピールを発表

$=21$ 世紀の環境保全に向けた自主行動宣言=

、「持続可能な発展」を実現するためのキーワード

- 環境倫理の再確認・自主的取り組みの強化

・エコ・エフィシェンシーの向上

4 つの「環境アピール」

- 地球温暖化の対策

・循環型社会の構築

廃棄物は, 資源・副産物と発想を転換

・環境管理システムの構築と環境監査の実施

・海外事業展開時の環境配慮

各業界は, 行動計画を作成

\section{4 環境問題が, 製品問題へと拡大してきた。}

現在の環境問題を根本から解決するためには, 従来の 公害災害問題から，経済・製品問題として取り組む必要 がある。

循環型社会構築のための行動が必要である。

製品に関する環境問題解決のアプローチは, 生産工程 のみならず設計段階での対応，さらには販売から廃棄ま での“製品の一生”を考えた活動が求められる。
公害問題から, 経済・製品問題に

部分的かつ消極的な活動から, 積極的で “設計” にさかのぼった活動に

“資源”の効率的な使用や，地球規模的な自然環境 保全が必要

“経営課題”そのあのに成ってきた

\section{製品に関する，環境問題}

\section{一開 発・製 造}

環境配慮型製品の開発促進

生産ラインは, 省資源・省エネ

$\rightarrow$ 商品の優位性を確保

> 購入

環境配慮型製品の優先的購入（グリーン購入）

$\rightarrow$ グリーン製品市場の形成

販売

廃製品の回収・再資源化

$\rightarrow$ 循環型社会づくり, 資源の枯渇対策

すべての工程で共通的なことは，すべての “無駄を排 除”することである。

設計段階での無駄の排除は，余分な機能を省いたりま た長期使用が可能な設計, モジュール設計による機能の 追加が可能な, まさに環境保全をトータル的な視点でみ た製品設計が求められている。

省資源・省エネルギーを基本とした環境配慮型の製品 開発が不可欠である。

製造段階での無駄の排除は，まず省資源・省エネル ギーの生産ラインを構築することである。さらに, 作り すぎをしない, 必要なときに必要な量だけを製造する生 産管理の見直しも必要である。

販売段階では, 流通の効率化による省エネルギーや過 剩梱包包装の排除なども必要な施策である。

使用済み商品については，消費者の協力のもと回収を 促進し，また再利用（原料としてまたは中古商品として 利用）するなどの活動が必要である。特に廃製品の回 収・リサイクルは，そのためにかなりの工数や費用が必 要であり，消費者・行政との連携なしには実現すること が非常に困難である。

\section{3. 当社の廃棄物削減・再資源化運動 $=\lceil$ 廃棄 物ゼロ運動」}

\section{1 「廃棄物ゼロ運動」}

当社では, 1985 年の廃棄物発生量の増加傾向に危機 感を持ち「廃棄物ゼロ運動」を全社的に展開した。

現在でも，パートIII して継続している。 


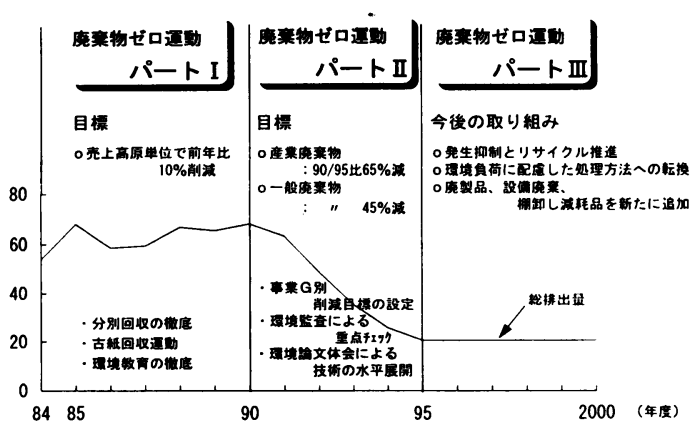

廃棄物削減活動の推移

この活動の特徴は,

・全社の削減数值目標を設定したこと。

・産業廃棄物と事業系一般廃棄物に分けて活動展開

・業際的な取り組みで，再資源化を促進

・結果は, 毎年実施する環境監査で確認する

・効果的な削減再資源化策は, 論文大会や環境ニュー スで全社的に展開する。

- 全員参加の活動として展開

等であり，大きな成果を上げることができた。

\section{2 廃棄物ゼロ運動パートIII」}

パートIIの成果を踏まえ新たな活動展開として, 96 年度からパート III 強力に推進している。

パートIIIでは，3つの視点で活動施策を設定した。

(1) 発生抑制とリサイクル推進

- 考え方

発生を回避 >リサイクル促進 $>$ 減量化処理 $>$ 最終 埋立て

・ 2000 年の委託処分量を, 95 年レベルに抑制

・ 2000 年の梱包廃プラのリサイクル率を $50 \%$ とす る

（2）環境負荷を考慮した処理の実施

・産業廃棄物の埋立て量を 2000 年には 90 年度比の

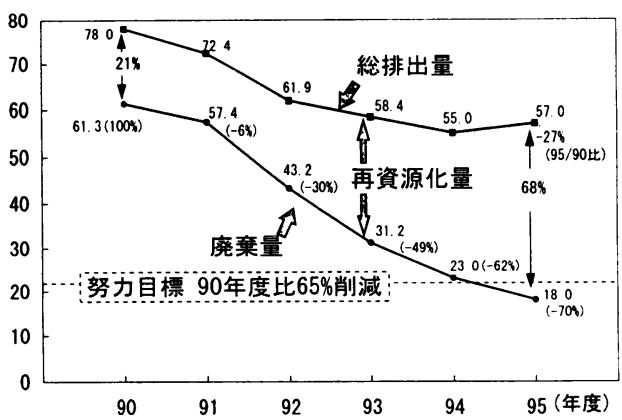

産業廃衰物（廃棄物ゼロ運動の成果）の推移

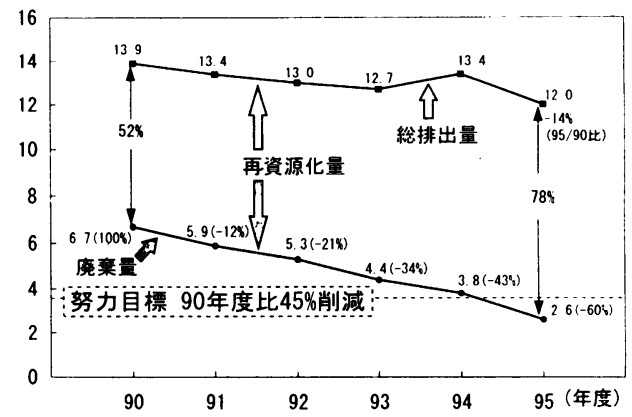

一般廃棄物（廃裹物ゼロ運動の成果）の推移

$1 / 10$

・リサイクルの優先順位

再使用>マテリアル・リサイクル>ケミカル・リ サイクル>サーマル・リサイクル

・焼却処理は, 極力回避サーマル・リサイクルなど への転換

（3）事業活動全域の廃棄物を管理対象に廃製品，廃設 備, 棚卸減耗品など

\section{3 廃棄物の再資源化活動}

廃棄物の発生量そのあのを削減することが基本ではあ るが，いかなる施策を実施してあ廃棄物量をぜロにする ことは極めて困難である。

そこで,これらの最終廃棄物を再原料として使う, す なわち再資愿化として利用している。この際に重要なこ とは，廃棄物を利用してあらえる企業を探すことである。 すなわち，業際的な取り組みを推進することである。

当社の全廃棄物発生量の約 $60 \%$ を排出している半導 体事業からの廃裹物の再資源化状況を紹介する。

(1) 再資源化する際の留意点。

・廃裹物の考え—メーカに引取ってあらう物は を捨てる 原料である。

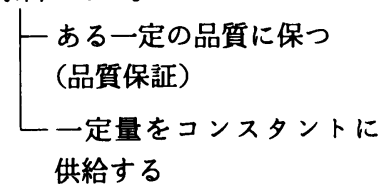

・なるべく近くに引取り手を探す 流通コストを低減させ，トータルの費用低減を図 る

・危険分散ため, 2 社購買もしくは最終処分先は継 続して確保しておく

(2) 分別回収に努め，再資源化が容易な状態とする。

（3）半導体製造会社の再資源化事例（次頁参照） 


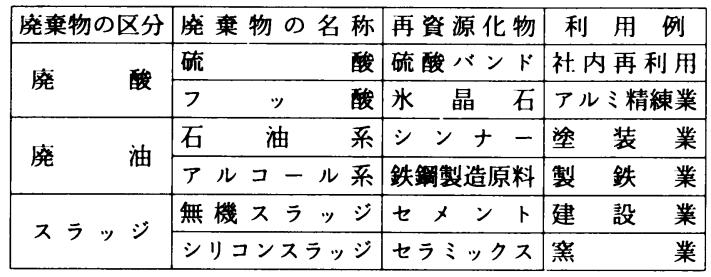

\section{4 廃棄物削減・再資源化の基本原則}

基本的な原則：適正処理処分と企業責任の全う

○極力出さない一源流対策 回収・再資源化

○出てきたもの一減量化, 減容化一 「廃衰物ゼロ 運動」で展開 適正処理・処分

\section{4. 環境管理システムの再構築}

ISO/TC 207 では，持続可能な開発と循環型社会づく りをめざし、環境保全にかかわる国際規格（環境管理シ ステム, 環境監查）を発行した。

すべての業界において, 中小の企業を含めより多くの 企業がこの規格に合致した行動をとることが期待される。 すべての企業は，なんらかの形で環境管理システムを 持っている。特にわが国においては, 労㗢安全衛生法や 消防法などでかなりしっかりした全社的な仕組みづくり を要求されている。

したがって, 各企業においては, この既存の環境管理 システムを国際規格に合致した管理システムに再構築す ることはそれほど大変なことではない。 ISO 14001 とは

1. 会社内で, 環境保全活動を組織的に展開するた めの「管理システム」

2. 業務担当と責任の所在を明確にし，業務手順を 文書化し活動の透明性を確保

3. 環境に与える負荷を認識し, 継続的な低減活動 と自主監查の実施

4. 全社員を対象とした，環境業務の管理システム

\subsection{ISO 14001 の要求事項は何か}

この国際規格の基本的な要求事項は, 企業の環境保全 活動において「環境に与えている負荷を認識すること」 と「その環境に与えている負荷を継続的に低減する活 動」をすることである。

すなわち, 持続可能な開発を維持・継続するための管 理システムである。

多くの企業にとって, この規格に適合するには, 環境
ISO 14001 の要求事項

$\diamond$ 規格の目的

「地球環境保全」と「公害防止」

（省資源・省エネルギー）（廃棄物削減・リサイクル）

$\diamond$ 適用範囲

「あらゆる分野・規模の企業」における

「トップダウンによる全員参加の活動」

$\diamond$ 要求事項

「継続的な改善」と「法規制の遵守」

（㻴境負荷の把握とその低減活動）（自主環境監查の実施）

影響評価の実施と内部監査においてシステム監査も行う ように既存のシステムを見直せば良い。

この ISO は, 環境影響評価や内部監查の具体的な方 法を示したものではない。

あくまで, 影響評価とシステム監査のしくみを社内に 持つことを要求しているにすぎない。

\subsection{ISO 14001 を導入すべきか}

あくまで, 経営トップが導入すべきかどうかを判断す べき事項である。

なぜならば，この環境管理システムは全社的な経営管 理システムの一つであり，また今まで社内においてそれ 程深い理解を得てないからである。

ISO 14001 を導入すべきか

1.「環境に配慮した行動」を活性化させる事ができる。

2. “経営方針”として決定する事項。

社外に対する，企業行動の証の一つになる

従来の環境管理システムを補完できる

3. 活動の透明性を高めることができる。

4. 社会や政府機関から,

規格に適合した行動の要請が来る可能性有り

海外の顧客から, 商取引の条件にされることはまれ

（むしろ, 環境情報の提供が求められる可能性が大）

$\rightarrow$ 活動活性化のためには, 有益な規格。

準備状況を見ながら導入を検討, 焦る必要はない。

\subsection{ISO 14001 を導入する際のポイント}

ISO を導入する際のポイントは，それ程大变なことと 思わないことである。

環境のISO と類似の規格として品質管理システム (ISO 9000) がある。

すでに国内において約 3000 の製品や企業がこの品質 のISO を導入している。多くの企業が, この品質の ISO の第 3 者審査を受審するために非常に多くの工数を かけた。

この時の, 大変だったというイメージが強く, 環境 


\section{導入時のポイント}

1、既存のシステムのどこが不適合かを見つける。 （全ての会社で何らかのシステムはある）

2. 認証取得を目的とはしない。 導入により，何かが変わる，効果が出るよう

3. 審査の受審は，優秀な企業を認めるためでない。 環境マインドの底上げ

より多くの企業が導入することが必要

4. 第 3 者審查は, 自社のシステムの適合性を 効率的かつ効果的に審查できる機関を選ぶ。

ISO 導入に対しても若干の拒絶反応があるのも事実であ る。

このISO 導入は，自社の環境保全活動の質が変わり また，全社的な活動となり環境保全活動の効果が出るよ うにすることが大切である。

第 3 者番查は，あくまで自社のシステムが ISO 14001 の要求事項に整合しているかどうかを，第 3 者の目で見 てもらい確証を得るためである。

\section{4 国際規格導入後のメリット：}

今までのシステムで，弱い箇所が補完される。

さらに，経営者の環境保全に関する意識が高まり，活 動が活性化することである。

また，企業イメージアップにあなり，情報公開に対す る基礎データもそろえることができる。

\section{導入後のメリット}

1. 環境管理活動が，全社的な取り組みとなり， 活性化する

2. 経営者の理解が高まり, 真の経営課題となる

3. 企業イメージアップにつながる $\Rightarrow$ 環境管理レベルが向上する

\section{5 当社の ISO 導入戦略}

導入に際しては, 余分の工数をかけず，かつ，導入後 NEC の ISO 導入戦略

1. EMS は,「ISO 14001」に準拠

2. まずノウハウを蓄積し，その後全社で展開 プロジェクトを組織化し，効率的に展開 特定の会社を選出し, 集中的に活動

3. 効率的かつ効果的な導入を図る

電子ッールを最大限活用

支援チームを組織化し，ノウハウを水平展開

4. 蕃査登録機関の選定は， $2 \sim 3$ 機関に絞る 当社の環境管理システムを効率的に審査できる事 品質管理システムの ISO との係わりを考慮
は何かが変わるような効果が出るような仕組みとする。 決して，認証取得だけに終わることがないように心が ける。

そのためには，既存の管理システムをベースに，ISO の要求事項を満足できるように再構築を図る。

\section{6 導入準備のプロセス}

規格の要求事項を，BS 7750 を参考に勉強した。

その後，全社一斉に準備に係るのではなく，代表的な 会社を数社選定し，その会社でノウハウの蓄積を図った。 すでに準備を始めてから約 3 年が経過し，かなりのノ ウハウ蓄積ができた。

JIS が発行される時期を一つのタイミングに，全社的 な展開の準備をしている。

NEC における, 導入準備のプロセス

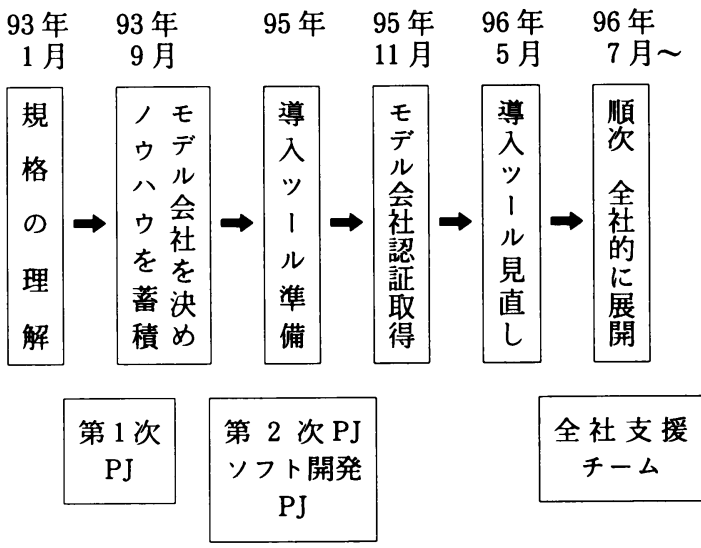

\subsection{ISO 14001 導入時期のガイドライン}

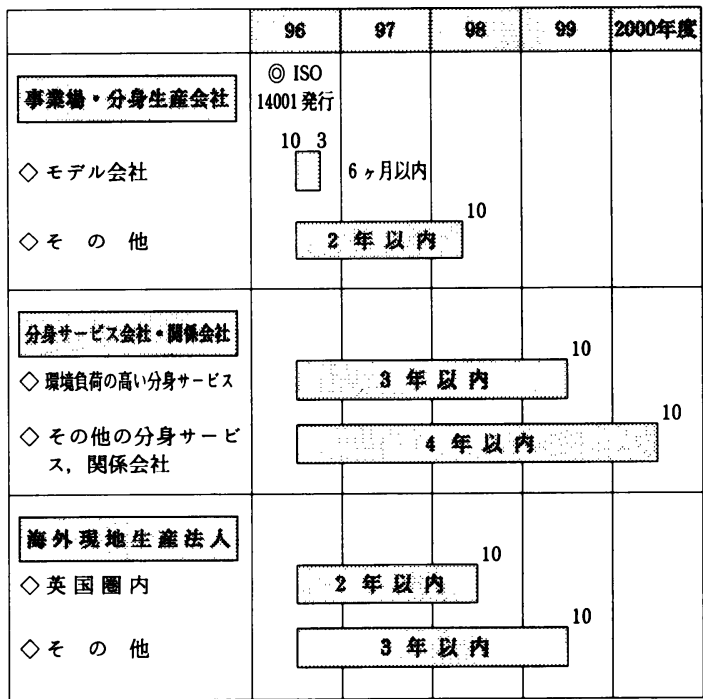

環境 ISO 導入への対応：認証取得時期のガイドライン 


\section{5. 今後の, 目指すべき方法}

(公害災害防止の徹底

資源の有効活用

持続可能な開発

の具体的な実行が，すべての企業に求められている。

○NEC は, より一層の, 環境にエクセレントな企業
を目指す。

[今後の重点課題]

○省エネルギー

$\diamond$ 環境配虑型製品の開発とグリーン調達

○廃製品の回収・リサイクル

৩グローバルな視点で, 活動展開

\title{
Environmental Preservation Activities of the Future
}

\author{
Koji Yamaguchi
}

General Manager, Environmental Management Div., NEC Corp.

(Shiba 5-7-1 Chome, Minato-ku, Tokyo 108-01 Japan)

\begin{abstract}
Environmental preservation activities in the future will require some substance and actions which are totally different from those of the past.

With regards to administration, the waste disposal law will be revised and the recycling law will be widely applied to the actual situation of the wastes. In the industrial world, as seen through the "Environmental Appeal" that Keidanren announced last July, they have already taken one step forward by creating a cycling society. This "Environmental Appeal" is appealing in that it asks each company to consider wastes as resources and by-products, and to establish an efficient resource use program. From the international perspective, the international standard organization, which has been issuing technical standards, has also started setting international standards regarding the environment. It has also issued an environmental management system and the environmental audit standards to check its system. At NEC we have established a company-wide target on wastes through zero-waste activities which have been carried out for 11 years and with which we have been achieving greater success every year. In such ways, waste reduction and recycling issues are a focal point and one of the easiest themes to promote in company-wide activities.
\end{abstract}

Key words : the revision of the waste disposal law, collecting and recycling of waste products, Keidanren Appeal, zero-waste activities, environmental management system 